\title{
EVALUATION OF EGYPTIAN TREE WILLOW (Salix safsafs) LEAVES AND ITS FEEDING AFFECT ON PRODUCTIVE PERFORMANCE OF NEW ZEALAND WHITE RABBITS.
}

\author{
M.M. Basyony, ', Eman, I. Abd El Gawad ${ }^{2}$ and Dohreig, R.M.A. ${ }^{3}$ \\ 1 Department Of Poultry Nutrition Research, Animal Production Research \\ Institute, Agricultural Research Center, Giza, Egypt; ${ }^{2}$ Department Of Sheep And \\ Goat Research, Animal Production Research Institute, Agricultural Research \\ Center, Giza, Egypt; ${ }^{3}$ Department Of A.I Research Institute, Agricultural Research \\ Center, Giza, Egypt. \\ Corresponding author: Mohamed Basyony Mohamed Mahmoud, E-mail: Address: \\ mohamed000basyony@yahoo.com.
}

The present study aimed to investigate the effects of replacing Berseem hay by different levels of Salix Safsaf hay in rabbit diet on growth performance, carcass, blood biochemical traits and antioxidant status. Weaned male New Zealand White (NZW) rabbits about 6 weeks old $(n=120$, mean body weight $701.15 \mathrm{~g})$ were randomly allotted to four dietary groups. The control group was fed a basal diet including $300 \mathrm{Kg} /$ Ton of Berseem hay(T1); the experimental groups received the basal diet replacement with 75, 150 and $225 \mathrm{Kg}$ /Ton Salix Safsaf hay of (300 Kg/Ton) Berseem hay diets (T2, T3 and T4), respectively).The experimental period lasted for 8 weeks.

Results showed that T4 had the best final body weight, body weight gain and feed conversion ratio. Dietary including Salix Safsaf hay improved digestible coefficient of Dry matter (DM), Organic matter $(O M)$, Crude protein $(C P)$, Ether extract $(E E)$ and nutritive values of Total digestible nutrient (TDN) and Digestible crude protein (DCP); Replacement of Salix Safsaf hay had no significant $(P<0.9858)$ effected on digestible coefficient of crude fiber as compared with control treatment. Treatment including 225 Salix Safsaf hay significantly increased $N$-intake (IN, g/day), digestible $N(D N, g / d)$, retained $N(R N$, $\mathrm{g} / \mathrm{d}$ ), the efficiency of intake $N$ converted into digestible $N$, the efficiency of intake $N$ converted into retained $N$ and the efficiency of digestible $N$ converted into digestible $N$ and caecum activity as Total volatile fatty acid (VFA). While significantly decreased urinary-N (UN, g/day) and caecum activity as NH3-N (mg\lOO dL) as compared with control treatment. Treatments including 75 Salix Safsaf hay increased carcass 
weight $(g)$ and total edible parts $\%$ as well as blood plasma albumine and glucose contents were increased ( $p \leq 0.0011$ and 0.05). Dietary contained Salix Safsaf hay decreased blood plasma total lipids, ( $\mathrm{mg} / \mathrm{l})$, triglycerides, (mg/dl), total cholesterol, $(\mathrm{mg} / \mathrm{dl})$, low-density lipoprotein, $(\mathrm{mg} / \mathrm{dl})$ very low-density lipoprotein, $(\mathrm{mg} / \mathrm{dl})$, aspartate aminotransferase,(IU) alanine aminotransferase, (IU), alkaline phosphatase, $(\mu l)(p \leq 0.0171,0.0190,0.0001,0.0015,0.0036,0.0511$, 0.0542 and 0.0532 ) respectively. Replacing 150 or 75 Berseem hay by 15 or 225 Salix Safsaf hay increased the blood plasma concentrations of creatinine and high-density lipoproteins. Total antioxidant capacity in blood increased $(p \leq 0.0001)$ for T4 treatment. However, malondialdehyde was reduced $(p \leq 0.001)$ when Salix Safsaf hay partial replaced Berseem hay in rabbit diet. Replacing Berseem hay in rabbit diets by Salix Safsaf hay reduced the feeding cost of experimental rabbits.

Keywords: Salix safsafs, growing rabbit, performance, digestibility coefficients, blood parameters, economic efficiency.

Since 2015, the price of feed ingredients exported from abroad had become very expensive in Egypt, which led to significant reduction in rooster production and high price of meat and fish. Urgent action is therefore required to solve the problems, including increasing rabbit's production. Rabbit meat is of high quality and safety. Rabbit is suitable to be raised for meat production due to its high feed conversion efficiency, high fecundity and short generation interval (de Blas and Garvey, 1975). Moreover, rabbits use protein more efficiently than broiler and up to $20 \%$ roughage can be included in their diet (Cheeke, 1986). In these circumstances, it is important to search nontraditional feeds in animal feeding having low cost and to raise the product and decreasing the marketing price of animal products. On the other side, with shortages of arable land, feed ingredients and water in many countries, rabbits can help in food production by conversion many agricultural byproducts into meat. Generally, there is no need to use prime forages for rabbit feeding, and there is no need to use grains that are fit for human consumption. The list of what ingredients can be incorporated into rabbit feed is enormous and growing continuously (Ibrahim, 2000). Although, the use of tree and shrub leaves by herbivores may be restricted by negative effects of secondary compounds on digestion (Provenza, 1995; Salem, 2005; Salem et al., 2006, 
2007). Rabbits have an acute sense of smell that enables them to find accepted plants. When they find a spot with available feeds, they will come back time and again until the supply is gone.

The Egyptian willow (Salix Safsaf) is a small tree growing in Egypt since pre-historic times. It is generally found in wet ground such as along water-ways. White willow which is also known as the salicin willow has been used for its health benefits for thousands of years (Saller et al., 2008). Its branches, being long, thin and pliant, Leaves, seeds, and other parts of the plant were used in medicine. In the Hearst medical papyrus seeds are recommended for cooling the vessels, and for cooling a bone after it has been set (Lise Manniche, 1989). The total $\mathrm{N}$ and ME content of willow fodder are about $26.3 \mathrm{~g}$ and 10.5 MJ per $\mathrm{kg} \mathrm{DM}$, respectively (ThiMui et al., 2005). Willow is moderately digestible and highly palatable for livestock and it is a source of minerals for grazing livestock, including calcium, magnesium, potassium and zinc (Guevara-Escobar, 1999). Willow species synthesize low molecular phenolic glycosides, such as salicin (35 g/kg DM) and/or condensed tannin (CT, $38 \mathrm{~g} / \mathrm{kg}$ DM) (Pitta et al., 2007). Salicin and salicortin are the primary salicylates found in white willow (salix safsaf). They are metabolized by intestinal flora to saligenin Julkunen-Tiitto and Meier (1992), absorbed into the blood stream, and metabolized by the liver to salicylic acid; excretion is primarily through renal (Bissettet, 1994 and Fotsch et al., 1989).

Therefore, the objective of the present work was to study the effect of feeding growing rabbits with different levels of stem and leave Salix Safsaf hay as partial replacement of Berseem hay, on growth performance, digestible coefficient of nutrients, nitrogen metabolism, carcass traits and blood biochemical characteristics.

\section{MATERIALS AND METHODS}

The experimental work of this study was carried out at Nobaria Animal production Research Station, Behara Governorate, Animal Production Research Institute, Egypt.

A total number of one hundred and twenty male New Zealand White rabbits aged 6 weeks with an average body weight of $701.15 \mathrm{~g}$, were divided into four equal groups each nine animals. The basal experimental diet was formulated and pelleted to cover the nutrient requirements of rabbits according to N.R.C (1977) as shown in (Table 1). Small stems and leaves of Salix Safsaf were collected from the trees which spread behind the branches 
Table (1): Composition ( $\mathrm{kg} / \mathrm{Tons})$ of the experimental diets:

\begin{tabular}{|lllll|}
\hline Ingredients & \multicolumn{4}{c|}{ Experimental diets } \\
\cline { 2 - 5 } & T1 & T2 & T3 & T4 \\
\hline Berseem hay & 300 & 225 & 150 & 75 \\
Salix safsaf & - & 75 & 150 & 225 \\
Barley grains & 200 & 200 & 200 & 200 \\
Plant Concentrate & 20 & 20 & 20 & 20 \\
Yellow corn & 100 & 100 & 100 & 100 \\
Wheat bran & 148.4 & 148.4 & 148.4 & 148.4 \\
Soybean meal 44\% CP & 180 & 180 & 180 & 180 \\
Molasses & 30 & 30 & 30 & 30 \\
Limestone & 10 & 10 & 10 & 10 \\
Di-Calcum phosphate & 5 & 5 & 5 & 5 \\
Sodium chloride & 3 & 3 & 3 & 3 \\
Vit-min premix & 3 & 3 & 3 & 3 \\
DL-Methionine & 0.6 & 0.6 & 0.6 & 0.6 \\
\hline Total & $\mathbf{1 0 0}$ & $\mathbf{1 0 0}$ & $\mathbf{1 0 0}$ & $\mathbf{1 0 0}$ \\
\hline *** Price LE & 4900 & 4700 & 4500 & 4300 \\
\hline * Vit. and Min. mixture: Each kilogram of Vit. and Min. mixture contains: 2000.000 IU \\
Vit. A, 150.000 IU Vita. D, 8.33 g Vit. E, 0.33 g Vit. K, 0.33 g Vit. B1, 1.0 g Vit. B2, \\
0.33g Vit. B6, 8.33 g Vit.B 5, 1.7 mg Vit. B 1,2 3.33 g Pantothenic acid, 33 mg Biotin, \\
0.83g Folic acid, 200 g Choline chloride, 11.7 g Zn, 12.5 g Fe, 16.6 mg Se, 16.6 mg Co, \\
66.7 g Mg and 5 g Mn.** LE=Egyptian pounds.
\end{tabular}

canals of the Nile River in Nobaria, El Behara Governorate Egypt. Salix Safsaf stems and leaves were left to sun-drying and kept in clean bags until to using in ration formulations. Chemical analysis of Salix safsaf stems and leaves was carried out according (AOAC, 1996). The feeding period was extended for 56 days.

The experimental groups were classified to four groups as follow:

Treatment 1 basal diet contained $300 \mathrm{Kg} / \mathrm{Ton}$ Berseem hay and served as control diet (T1).Treatment 2 basal diet contained 75 Salix safsaf +225 Berseem hay $\mathrm{Kg}$ /Ton (T2).Treatment 3 basal diet contained 150 Salix safsaf + 150 Berseem hay $\mathrm{Kg} / \mathrm{Ton}$ (T3).Treatment 4 basal diet contained 225 Salix safsaf + 75 Berseem hay $\mathrm{Kg} / \mathrm{Ton}$ (T4).

Rabbits were individually housed in galvanized wire cages $(30$ x 35 x 40 $\mathrm{cm})$. Stainless steel nipples for drinking and feeders allowing recording individual feed intake for each rabbit were supplied for each cage. Feed and water were offered ad libitum. Rabbits of all groups were kept under the same 
managerial conditions and were individually weighed and feed consumption was individually recorded weekly during the experimental period.

\section{Digestibility and nitrogen balance trials:}

At the end of the experimental period, all rabbits were used in digestibility trials over period of 7 days to determine the nutrient digestibility coefficients and nutritive values of the tested diets. Feces were daily collected quantitatively. Feed intake of experimental rations and weight of feces were daily recorded. Representative samples of feces was dried at $60^{\circ} \mathrm{C}$ for $48 \mathrm{hrs}$, ground and stored for proximate chemical analysis. Samples of feed and feces were analyzed for dry matter (DM), crude protein (CP), ether extract (EE), crude fiber (CF), and ash according to the classical (AOAC, 1996) methods. The nutritive value of the experimental diets as DCP and TDN value were calculated according to Cheeke, et al. (2013). Neutral detergent fiber (NDF), acid detergent fiber (ADF) and acid detergent lignin (ADL) were also determined in the experimental rations according to Goering and Van Soest (1970).

Hemicellulose was calculated as the difference between NDF and ADF, while cellulose was calculated as the difference between ADF and ADL. Gross energy (kilo calories per kilogram DM) was calculated according to Blaxter (1968), where, each $\mathrm{g}$ of crude protein $(\mathrm{CP})=5.65 \mathrm{kcal}$, each $\mathrm{g}$ of ether extract $(\mathrm{EE})=9.40 \mathrm{kcal}$ and each $\mathrm{g}$ crude fiber $(\mathrm{CF})$ and nitrogen- free extract $(\mathrm{NFE})=$ $4.15 \mathrm{kcal}$. Digestible energy (DE) was calculated according to Fekete and Gippert (1986) using the following equation: DE $(\mathrm{kcal} / \mathrm{kg} \mathrm{DM})=4253-32.6$ (CF \%)- 144.4 (total ash). Non fibrous carbohydrates (NFC) were calculated according to Calsamiglia et al. (1995) using the following equation:

$$
\mathrm{NFC}=100-\{\mathrm{CP}+\mathrm{EE}+\mathrm{Ash}+\mathrm{NDF}\} \text {. }
$$

The CT of salix safsaf was determined according to Makkar (2003), salicin and phenolic compounds were determined using the high-performance liquid chromatographic using the procedure of Meier et al. (1988). The urine of each animal was collected in a glass recipient, containing $10 \mathrm{ml}$ of a 1:1 $\mathrm{HCl}$ : $\mathrm{H} 2 \mathrm{O}$ solution, to avoid bacterial production and possible losses by volatilization. The chemical composition of feces, urine and feed was determined according to the methodologies described by Silva and Queiroz (2002). The values of nitrogen consumption, nitrogen excreted in feces and nitrogen excreted in urine were obtained by multiplying nitrogen levels by the amounts of feed ingested and of feces and urine excreted, respectively; from those values. Nitrogen balance was calculated as $\%$ of nitrogen intake. 


\section{Slaughtering and carcass traits:}

At the end of the experimental period ( 8 weeks), six male rabbits from each group were randomly taken, fasted for $12 \mathrm{~h}$, individually weighed and immediately slaughtered. Slaughter procedure and carcass analysis were carried out as described by Blasco et al. (1993). After complete bleeding, pelt, viscera's and tail were removed then the carcass and its components were weighed as edible parts. The non edible parts including lung, spleen, stomach, large intestine, small intestine and kidney fat were also weighed as percentage of preslaughter weight. Dressing percentage was calculated by dividing the hot dressed carcass weight by pre-slaughter weight and expressed as a percentage according to Steven et al. (1981).

\section{Blood Sampling and determination of biochemical parameters:}

Blood samples of five rabbits from each dietary treatment $(5 \mathrm{ml}$ from each rabbit) were collected during slaughtering to determine blood measurements. Plasma was separated from blood by centrifugation at $1000 \mathrm{~g}$ for $20 \mathrm{~min}$ and stored at $-20^{\circ} \mathrm{C}$ till assayed. Plasma total protein, albumin, triglycerides, total cholesterol, LDL and HDL-cholesterol, vLDL, and total lipids were calorimetrically determined using commercial kits (purchased from Bio-diagnostic, Egypt) according to the manufacturers' instructions. Plasma globulin concentration was calculated by the difference between total protein and albumin. Glucose was determined according to Trinder (1969). Aspartate aminotransferase (AST) and alanine aminotransferase (ALT) were assayed according to Fawcett and Soctt (1960), plasma lipid peroxidation activity was assayed using the method of Chiu et al., (1976). Total antioxidant capacity (TAC) was determined according to Diamond Bio diagnostic, Egypt. Alkaline phosphatase was determined by calorimetric method of Szasz, (1969). Plasma creatinine was assayed according to Caraway, (1963). Urea nitrogen was measured by means of spectrophotometer according to Fawcett and Soctt (1960).

\section{Relative economic efficiency:}

The relative economic efficiency of the experimental diets for the cost of feed required for producing one $\mathrm{kg}$ of body weight gain were calculated. The cost of the experimental diets was calculated according to the price of different ingredients prevailing in local market, as well as, the price of testing materials at the time of experimentation. Economic efficiency was calculated as a ratio between the return of weight gain and the cost of consumed feed.

\section{Statistical Analysis:}

The experimental design was completely randomized using the General Linear Means of SAS (2001). Measured parameters were analyzed using the following statistical model: 


$$
Y i j=\mu+d i+\varepsilon i j .
$$

Where yij is the value measured, $\mu$ is the overall mean effect, di is the ith diet effect and cij is the random error associated with the jth rabbits assigned to the ith diet. Significant differences of $\mathrm{P}<0.05$ among means were determined using Duncan's Multiple Range Test (Duncan ,1955).

\section{RESULTS AND DISCUSSION}

Chemical analysis and cell wall constituents of the tested materials and the experimental diets are presented in Table 2. The chemical composition of Salix safsaf as crude protein, ether extract, ash, gross energy, hemicelluloses, cellulose, dry matter, organic matter, crude fiber, nitrogen-free extract, digestible energy (Kcal/kg DM), non fibrous carbohydrates, acid detergent lignin, acid detergent fiber and neutral detergent fiber contents were in the same range for both stems and leaves of Salix safsaf and Berseem hay.

Salix hay contained an adequate amount of N, DM, organic matter, crude protein, $\mathrm{NDF}, \mathrm{ADF}$ and $\mathrm{DE}$, which support moderate growth of livestock (McWilliam 2004). Jo Smith et al (2014) reported that leaves + stem of willow tree contained $167 \mathrm{~g} / \mathrm{kg}$ crude protein on dry matter (DM), while the Neutral detergent fibre, Acid detergent fiber and lignin concentration were 573, 410 and $184 \mathrm{~g} / \mathrm{Kg}$ dry matter, respectively. However, the organic matter digestibility determined by in vitro pepsin-cellulase method was low (0.405 for leaf + stem) and it might be suitable for other animal groups with lower energy requirements. No condensed tannins (CT) or salicin was detected in Berseem hay but salix safsaf had a relatively moderate (CT) and high salicin contents, (Table 2). The stems and leaves of Salix safsaf contained substantial concentrations of secondary metabolites, including lignin, CT, salicin and other phenolic compounds. The experimental diets were iso caloric and iso nitrogenous. Protein contents for the four tested rations $\left(T_{1}-T_{4}\right)$ ranged from 16.89 to $17.11 \%$, the digestible energy values ranged from 2557 to 2616 (kcal/ $\mathrm{kg}$ DM) for all diets. All parameters determined of chemical analysis were similar for the different experimental diets regardless the phytochemicals content of used Salix safsaf.

\section{Nutrient digestibility and nutritive values:}

Digestibility coefficients and nutritive values (\%) of the experimental diets are shown in Table 3. Dietary treatments had no significant effects on crude fiber digestibility coefficients. Significant effects on crude fiber 
Table (2): Chemical analysis and cell wall constituents (\%) of the tested materials and the experimental diets.

\begin{tabular}{|c|c|c|c|c|c|c|}
\hline \multirow[b]{2}{*}{ Items } & \multicolumn{2}{|c|}{ Tested materials } & \multicolumn{4}{|c|}{ Experimental diets } \\
\hline & $\begin{array}{l}\text { Berseem } \\
\text { hay }\end{array}$ & $\begin{array}{l}\text { Salix safsaf } \\
\text { (stems + } \\
\text { leaf) }\end{array}$ & T1 & $\mathbf{T} 2$ & T3 & T4 \\
\hline \multicolumn{7}{|l|}{ Chemical analysis (\%) } \\
\hline Dry matter & 91.5 & 90.47 & 90.5 & 91.22 & 91.07 & 91.23 \\
\hline \multicolumn{7}{|c|}{ Chemical analysis on DM basis } \\
\hline Organic matter $(\mathrm{OM})$ & 88.03 & 86.21 & 91.29 & 91.58 & 91.37 & 91.41 \\
\hline Crude protein $(\mathrm{CP})$ & 11.18 & 12.25 & 16.89 & 16.97 & 17.11 & 17.02 \\
\hline Crude fiber $(\mathrm{CF})$ & 25.91 & 22.87 & 13.43 & 12.89 & 13.20 & 13.23 \\
\hline Ether extract (EE) & 1.67 & 3.26 & 2.94 & 2.97 & 2.99 & 2.98 \\
\hline Nitrogen-free extract (NFE) & 49.27 & 47.83 & 58.03 & 58.39 & 58.07 & 58.18 \\
\hline Ash & 11.97 & 13.79 & 8.71 & 8.42 & 8.63 & 8.59 \\
\hline Gross energy $(\mathrm{Kcal} / \mathrm{kg} \mathrm{DM})^{1}$ & 3908.6 & 3932.6 & 4196.2 & 4196.1 & 4205.4 & 4205.2 \\
\hline $\begin{array}{l}\text { Digestible energy } \\
(\mathrm{Kcal} / \mathrm{kg} \mathrm{DM})^{2}\end{array}$ & 1679.9 & 1516.2 & 2557.5 & 2616.9 & 2576.5 & 2581.3 \\
\hline $\begin{array}{l}\text { Non fibrous } \\
\text { carbohydrates }(\mathrm{NFC})^{3}\end{array}$ & 29.2 & 26.8 & 33.7 & 34.3 & 33.7 & 33.8 \\
\hline \multicolumn{7}{|l|}{ Cell wall constituents } \\
\hline $\begin{array}{lll}\text { Neutral } & \text { detergent } & \text { fiber } \\
\text { (NDF) } & & \end{array}$ & 45.943 & 43.946 & 37.74 & 37.39 & 37.59 & 37.61 \\
\hline Acid detergent fiber (ADF) & 40.9 & 38.7 & 22.5 & 22.2 & 22.4 & 22.4 \\
\hline Acid detergent lignin (ADL) & 27.3 & 22.7 & 10.3 & 8.8 & 9.4 & 9.9 \\
\hline Hemicellulose & 5.0 & 5.3 & 15.2 & 15.1 & 15.2 & 15.2 \\
\hline Cellulose & 13.6 & 15.9 & 12.3 & 13.4 & 13.0 & 12.5 \\
\hline Phenolic compounds & ND & 8.32 & ND & ND & ND & ND \\
\hline Condensed tannins & ND & \multirow{2}{*}{$\begin{array}{l}3.7 \\
12\end{array}$} & ND & ND & ND & ND \\
\hline Salicin (g/kg dry matter) & ND & & ND & ND & ND & ND \\
\hline
\end{tabular}

1 Gross energy (kilo calories per kilogram DM) was calculated according to Blaxter (1968), where, each $\mathrm{g}$ of crude protein $(\mathrm{CP})=5.65 \mathrm{kcal}$, each $\mathrm{g}$ of ether extract $(\mathrm{EE})=9.40 \mathrm{kcal}$ and each $\mathrm{g}$ crude fiber $(\mathrm{CF})$ and nitrogen-free extract $(\mathrm{NFE})=4.15 \mathrm{kcal}$.

2Digestible energy (DE) was calculated according to Fekete and Gippert (1986) using the following equation: $\quad \mathrm{DE}(\mathrm{kcal} / \mathrm{kg} \mathrm{DM})=4253-32.6(\mathrm{CF} \%)-144.4$ (total ash).

3 Non fibrous carbohydrates (NFC), calculated according to Calsamiglia et al. (1995) using the following equation: NFC $=100-\{\mathrm{CP}+\mathrm{EE}+\mathrm{Ash}+\mathrm{NDF}\}$. Hemicellulose $=$ NDF-ADF. Cellulose $=$ ADF-ADL. ND: Not determines.

digestibility coefficients. Rabbits received (150 salix safsaf +150 Berseem hay or 225 salix safsaf +75 Berseem hay $\mathrm{Kg} / \mathrm{Ton})$ diet recorded the highest digestibility coefficients of DM, CP and nutritive values as (TDN and DCP). Increased digestibility and $\mathrm{N}$-utilization may be due to positive impacts of salix safsaf on absorption and utilization of nutrients. Low to medium concentrations of CT $(20-40 \mathrm{~g} / \mathrm{kg}$ DM) occurred in willow forages, 
Table (3): Digestibility coefficients and nutritive values (\%) of the experimental diets.

\begin{tabular}{|c|c|c|c|c|c|c|}
\hline \multirow{2}{*}{ Item } & \multicolumn{4}{|c|}{ Experimental diets } & \multirow{2}{*}{ SEM } & \multirow{2}{*}{$P$ value } \\
\hline & T1 & T2 & T3 & T4 & & \\
\hline \multicolumn{7}{|l|}{ Digestibility coefficients: } \\
\hline Dry matter (DM) & $60.28^{b}$ & $65.56^{\mathrm{ab}}$ & $68.12^{\mathrm{a}}$ & $70.83^{\mathrm{a}}$ & 1.48 & 0.0400 \\
\hline Organic matter(OM) & $72.33^{\mathrm{b}}$ & $75.07^{\mathrm{ab}}$ & $76.62^{\text {ab }}$ & $77.56^{\mathrm{a}}$ & 0.90 & 0.0400 \\
\hline Crude protein $(\mathrm{CP})$ & $75.10^{b}$ & $76.20^{\mathrm{b}}$ & $79.01^{\mathrm{a}}$ & $79.00^{\mathrm{a}}$ & 0.28 & 0.0003 \\
\hline Crude fiber $(\mathrm{CF})$ & 54.344 & 55.979 & 56.334 & 56.334 & 3.41 & 0.9858 \\
\hline Ether extract $(\mathrm{EE})$ & $65.20^{b}$ & $66.03^{b}$ & $70.86^{\mathrm{a}}$ & $67.95^{\mathrm{ab}}$ & 1.05 & 0.0500 \\
\hline $\begin{array}{l}\text { Nitrogen-free } \quad \text { extract } \\
(\mathrm{NFE})\end{array}$ & $78.24^{b}$ & $80.45^{\mathrm{ab}}$ & $81.61^{\mathrm{ab}}$ & $82.37^{\mathrm{a}}$ & 0.70 & 0.0090 \\
\hline \multicolumn{7}{|c|}{ Nutritive values and nitrogen balance: } \\
\hline $\begin{array}{l}\text { Total digestible nutrient } \\
(\mathrm{TDN})\end{array}$ & $67.78^{b}$ & $69.97^{\mathrm{ab}}$ & $72.09^{\mathrm{a}}$ & $72.75^{\mathrm{a}}$ & 0.85 & 0.0300 \\
\hline $\begin{array}{l}\text { Digestible crude protein } \\
\text { (DCP) }\end{array}$ & $12.69^{\mathrm{c}}$ & $12.93^{b}$ & $13.52^{\mathrm{a}}$ & $13.44^{\mathrm{a}}$ & 0.05 & 0.0001 \\
\hline
\end{tabular}

a, $b$ and c: Means in the same row having different superscripts differ significantly $(\mathrm{P}<0.05)$.

$\mathrm{SEM}=$ Standard error of the mean.

increased the efficiency of protein digestion by increasing flow of $\mathrm{N}$ to the intestine relative to $\mathrm{N}$ intake, increased flow of essential amino acids out of the abomasum by $50-53 \%$ and increased net absorption of essential amino acids from the small intestine by 59-63\%, with no effect on digestibility (McWilliam, 2004). While, Rabbits received (225 salix safsaf +75 Berseem hay $\mathrm{Kg} / \mathrm{Ton}$ ) diet recorded the highest digestibility coefficients of $\mathrm{OM}$ and NFE. These results may be due to that rabbits have the ability to adjust its voluntary feed intake in response to changes in dietary energy concentration (Partridge et al., 1989). Rabbits fed on 150 salix safsaf +150 Berseem hay $\mathrm{Kg} / \mathrm{Ton})$ diet recorded the highest digestibility coefficients of EE. These results may be due to the limit dose of polyphenol from (SBP) has ability to inhibit alpha-amylase that may influence different steps in starch digestion in a synergistic manner (McDougall et al., 2005).

\section{Growth performance}

The experimental treatments of productive performance are presented in Table 4. Dietary stems and leaves of Salix safsaf hay (T4) treatment significantly $(\mathrm{P}<0.05)$ increased the final body weight, total body weight gain and average daily gain, while showed insignificant effects $(P>0.05)$ on feed intake. The increased growth rate in rabbits fed T4 may be due to increased 
Table (4): Growth performance traits of the experimental groups.

\begin{tabular}{|c|c|c|c|c|c|c|}
\hline \multirow{2}{*}{ Item } & \multicolumn{4}{|c|}{ Experimental diets } & \multirow{2}{*}{ SEM } & \multirow{2}{*}{$\begin{array}{c}P \text { - } \\
\text { value }\end{array}$} \\
\hline & T1 & T2 & T3 & T4 & & \\
\hline Initial weight, $\mathrm{g}$ & 705.83 & 703.75 & 697.50 & 697.50 & 15.84 & 0.9849 \\
\hline Final weight, $\mathrm{g}$ & $1997.08^{\mathrm{c}}$ & $1983.17^{\mathrm{c}}$ & $2052.08^{b}$ & $2119.17^{\mathrm{a}}$ & 17.69 & 0.0001 \\
\hline Body weight gain, $g$ & $1291.25^{b}$ & $1279.42^{b}$ & $1348.75^{\text {ab }}$ & $1421.67^{\mathrm{a}}$ & 25.34 & 0.0012 \\
\hline \multicolumn{7}{|l|}{ Duration period, 56 days } \\
\hline Average daily gain, $\mathrm{g}$ & $23.06^{\mathrm{b}}$ & $22.85^{b}$ & $24.09^{\mathrm{ab}}$ & $25.39^{\mathrm{a}}$ & 0.45 & 0.0012 \\
\hline \multicolumn{7}{|l|}{ Feed intake as: } \\
\hline Dry matter, g/h/d (DMI) & 97.29 & 96.33 & 96.27 & 94.86 & 0.94 & 0.3846 \\
\hline Crude protein , g/h/d (CPI) & 16.43 & 16.34 & 16.48 & 16.15 & 0.16 & 0.4990 \\
\hline $\begin{array}{l}\text { Digestible crude protein, } \mathrm{g} / \mathrm{h} / \mathrm{d} \\
\text { (DCPI) }\end{array}$ & $12.34^{\mathrm{c}}$ & $12.45^{\mathrm{bc}}$ & $13.02^{\mathrm{a}}$ & $12.76^{\mathrm{ab}}$ & 0.13 & 0.0022 \\
\hline $\begin{array}{l}\text { Total digestible nutrient, } \mathrm{g} / \mathrm{h} / \mathrm{d} \\
\text { (TDNI) }\end{array}$ & $65.94^{\mathrm{b}}$ & $67.38^{\mathrm{ab}}$ & $69.39^{\mathrm{a}}$ & $69.00^{\mathrm{a}}$ & 0.76 & 0.0107 \\
\hline Digestible energy, kcal/h/d (DEI) & 248.81 & 252.08 & 248.05 & 244.86 & 2.44 & 0.2685 \\
\hline \multicolumn{7}{|c|}{ Feed conversion (g intake/g gain): } \\
\hline Dry matter & $4.23^{\mathrm{a}}$ & $4.25^{\mathrm{a}}$ & $4.02^{\mathrm{a}}$ & $3.75^{\mathrm{b}}$ & 0.08 & 0.0008 \\
\hline Crude protein & 0.588 & 0.564 & 0.596 & 0.576 & 0.018 & 0.6264 \\
\hline Digestible crude protein & 0.442 & 0.430 & 0.471 & 0.455 & 0.014 & 0.2125 \\
\hline Total digestible nutrient & 2.362 & 2.323 & 2.511 & 2.461 & 0.07 & 0.3018 \\
\hline $\begin{array}{l}\text { Digestible energy (Kcal intake/g } \\
\text { gain) }\end{array}$ & 8.896 & 8.702 & 8.979 & 8.733 & 0.27 & 0.8821 \\
\hline
\end{tabular}

$\mathrm{SEM}=$ Standard error of the mean.

feed utilization in this group Table (3) and could be due to an increased digestibility and N-utilization (McWilliam, 2004). These results was in agreement with Salma et al (2014) who found that final live body weight, average daily gain, feed intake and feed efficiency of rabbits fed Salix tetrasperma hay replacement with $25 \%$ and $50 \%$ of Berseem hay were higher $(\mathrm{P}<0.05)$ than those fed $75 \%$ and the control. Also, Al-Fataftah and Abdelqader (2013) reported that broiler birds provided with Salix babylonica extracts in drinking water exhibited the maximum final BW, average daily gain and feed conversion improved compared with other groups.

Rabbits received (225 salix safsaf +75 Berseem hay $\mathrm{Kg} / \mathrm{Ton}$ ) diet increased the final body weight, total body weight gain and average daily gain $6.11,10.10$ and $10.10 \%$, respectively. So, results indicate that the responses to dietary tannin are variable and depend on the type, source and concentration of tannin used, animal species and basal diet fed. Maertens et al., (2005) showed that rabbits fed the tannin enriched diet at 57 days reached a live weight higher by $6 \%(P<0.01)$ with a daily weight gain comparable with 
control group. Rizzi and Chiericato (2008) demonstrated that the use of Salix alba for growing rabbits allowed a better productive performance.

Dietary stems and leaves of Salix safsaf hay treatments insignificant $(\mathrm{P}>0.05)$ decreased feed intakes of (DM, CP and DE) compared with control diets. However, rabbits fed on T3 and T4 diets recorded the highest digestible crude protein, g/h/d (DCPI) and total digestible nutrient, g/h/d (TDNI) dry matter intake.

These results were accepted with Barry and McNabb, (1999) who reported that condensed tannins increases protein absorption and utilisation by binding strongly to proteins to form a $\mathrm{pH}$-dependent complex, which is not degradable at normal rumen $\mathrm{pH}(6.0-7.0)$, but disassociates at normal abomasal $\mathrm{pH}(2.5-3.5)$ with the protein absorbed from the small intestine. However, phenolic glycosides, salicin + other phenolic glycosides could be an important source of glucose to increase the synthesis of rumen microbial protein. Also, fiber is one of dietary components which usually contain 35 to $40 \%$ neutral detergent fiber (De Blas and Mateos, 1998). It helps to maintain a high rate of passage, avoiding the accumulation of digesta in the caecum that reduce feed intake and impairs growth (De Blas et al., 1999).

Dietary stems and leaves of Salix safsaf treatments significantly $(\mathrm{P}<0.05)$ improved feed conversion ratio (g intake /g gain) of DM. Also, feed conversion (g intake /g gain) of CP, DCP, TDN and (kcal intake /g gain) of DE were improved when Salix safsaf used as a partial substitute of Berseem hay in rabbit diets. The best feed conversion was recorded by the rabbits that fed on $\mathrm{T} 2$ diet.

\section{Nitrogen balance and caecum activity}

The effect of replacement Salix safsaf at different levels of Berseem hay on nitrogen metabolism and caecum activity are shown in Table 5. The fecal $\mathrm{N}(\mathrm{FN})$ had no significant affected $(\mathrm{p}=0.1795)$ by replacement salix safsaf with Berseem hay, while $\mathrm{N}(\mathrm{IN})$, digestible $\mathrm{N}(\mathrm{DN})$, retained $\mathrm{N}(\mathrm{RN})$, the efficiency of intake $\mathrm{N}$ converted into digestible $\mathrm{N}$ (DN/IN), the efficiency of intake $\mathrm{N}$ converted into retained $\mathrm{N}(\mathrm{RN} / \mathrm{IN})$ and the efficiency of digestible $\mathrm{N}$ converted into digestible $\mathrm{N}$ (RN/DN) significantly increased with the salix safsaf levels increase $(\mathrm{p}=0.011,0.0012,0.0101,0.0522,0.05$ and 0.0115 , respectively). 
Table (5): Nitrogen metabolism and Caecum activity of the experimental groups.

\begin{tabular}{|c|c|c|c|c|c|c|}
\hline \multirow{2}{*}{ Item } & \multicolumn{4}{|c|}{ Treatments } & \multirow{2}{*}{ SEM } & \multirow{2}{*}{$P$ value } \\
\hline & T1 & T2 & T3 & T4 & & \\
\hline $\mathrm{N}$-intake (IN, g/day) & $3.08^{\mathrm{b}}$ & $3.17^{\mathrm{b}}$ & $3.26^{\mathrm{ab}}$ & $3.65^{\mathrm{a}}$ & 0.19 & 0.0114 \\
\hline Faecal-N (FN, g/day) & 1.08 & 1.09 & 1.17 & 1.15 & 0.21 & 0.1795 \\
\hline Urinary-N (UN, g/day) & $0.97^{\mathrm{a}}$ & $0.98^{\mathrm{a}}$ & $0.81^{\mathrm{ab}}$ & $0.73^{\mathrm{b}}$ & 0.11 & 0.0500 \\
\hline Digestible N (DN, g/d) & $2.00^{\mathrm{b}}$ & $2.08^{\mathrm{b}}$ & $2.09^{b}$ & $2.50^{\mathrm{a}}$ & 0.73 & 0.0012 \\
\hline Retained $N(\mathrm{RN}, \mathrm{g} / \mathrm{d})^{2}$ & $1.03^{\mathrm{b}}$ & $1.10^{\mathrm{b}}$ & $1.28^{\mathrm{ab}}$ & $1.77^{\mathrm{a}}$ & 0.09 & 0.0101 \\
\hline DN/IN $(\%)^{3}$ & $64.94^{b}$ & $65.61^{\mathrm{b}}$ & $64.11^{b}$ & $68.49^{\mathrm{a}}$ & 1.70 & 0.0500 \\
\hline $\mathrm{RN} / \mathrm{IN}(\%)^{4}$ & $33.44^{\mathrm{b}}$ & $34.70^{b}$ & $39.26^{b}$ & $48.49^{\mathrm{a}}$ & 1.16 & 0.0500 \\
\hline RN/DN $(\%)^{5}$ & $51.50^{\mathrm{c}}$ & $52.89^{c}$ & $61.24^{\mathrm{b}}$ & $70.8^{\mathrm{a}}$ & 2.99 & 0.0361 \\
\hline \multicolumn{7}{|l|}{ Caecum activity } \\
\hline $\mathrm{pH}$ value & 6.37 & 6.29 & 6.11 & 6.07 & 1.31 & 0.1500 \\
\hline NH3-N (mgl100 dL) & $34.52^{\mathrm{a}}$ & $29.72^{\mathrm{ab}}$ & $28.41^{b}$ & $24.30^{\mathrm{b}}$ & 0.59 & 0.0425 \\
\hline TVFA $(\mathrm{mmol} / 100 \mathrm{ml})$ & $5.83^{\mathrm{b}}$ & $5.97^{\mathrm{b}}$ & $5.93^{\mathrm{b}}$ & $6.87^{\mathrm{a}}$ & 0.17 & 0.0115 \\
\hline
\end{tabular}

$\boldsymbol{a}$ and $\mathrm{b}:$ Means in the same row having different superscripts differ significantly $(\mathrm{P}<0.05)$ $\mathrm{SEM}=$ Sstandard error of the mean.

${ }^{1} \mathrm{DN}=\mathrm{IN}-\square \mathrm{FN} .{ }^{2} \mathrm{RN}=\mathrm{IN} \square-\mathrm{FN} \square-\mathrm{UN} .{ }^{3} \mathrm{DN} / \mathrm{IN}(\%)=$ the efficiency of intake $\mathrm{N}$ converted into digestible $\mathrm{N}$.

${ }^{4} \mathrm{RN} / \mathrm{IN}(\%)=$ Efficiency of intake $\mathrm{N}$ converted into retained N. ${ }^{5} \mathrm{RN} / \mathrm{DN}(\%)=$ the efficiency of digestible $\mathrm{N}$ converted into digestible $\mathrm{N}$.

In the term of the cecum activity, the NH3-N $(m g \backslash 100 \mathrm{dL})$ significantly decreased $(\mathrm{p}=0.0425)$, while total VFA values were higher $(\mathrm{P}<0.05)$ with rabbit groups fed on $(225$ salix safsaf +75 Berseem hay $\mathrm{Kg} / \mathrm{Ton})$ diet $(6.87 \mathrm{mleq} / 100 \mathrm{ml})$. Dietary administration of stems and leave salix safsaf to young rabbits from weaning, improved biochemical traits of caecum content: the lower NH3 (24.30 versus $34.52 \mathrm{mg} \backslash 100 \mathrm{dL} ; \mathrm{P}<0.0425$ ) and $\mathrm{pH}$ values $(6.07$ versus $6.37 ; \mathrm{P}>0.05)$ and the TVFA content $(6.87$ versus $5.83 \mathrm{mmol} / 100 \mathrm{ml}$; $\mathrm{P}<0.0115$ ) indicated a higher fermentation of gut microflora. Volatile fatty acids (VFAs) produced as a result of caecal fermentation of digestible fibre or undigested nutrients provide a vital source of energy for the rabbits (Nicodemus et al., 1999). Also, decreasing acid detergent lignin (ADL) inclusion linearly increased caecal VFA concentration of growing rabbits (Table 2). These values are in general agreement with those obtained by García et al. (2002). In addition, no effect was observed on $\mathrm{PH}$ value among the treatments $(\mathrm{P}>0.05)$. Also, Salma et al. (2014) reported that rabbits fed diet containing 50\% Salix tetrasperma hay as Berseem hay replacement had the highest $(\mathrm{P}<0.05) \mathrm{N}$ balance and $\mathrm{N}$ digested values compared to other groups(25 and $50 \%)$. 


\section{Carcass traits}

The effect of stems and leaves of salix safsaf hay inclusion on the carcass characteristics of rabbits is shown in Table 6 . The obtained results revealed that significant increases $(\mathrm{P}<0.05)$ in hot carcass weight and total edible parts $\%$ of rabbits fed on diet (T2). While, dressing \%, edible giblets $\%$ and total non edible parts $\%$ had no significant affected $(\mathrm{P}>0.05)$ by replacement salix safsaf with Berseem hay. These results are in agreement with Salma et al. (2014) who found that partial replacement of Berseem hay with Salix tetrasperma hay at $75 \%$ of rabbits diets had the highest $(\mathrm{P}<0.05)$ carcass performance compared with $25 \%, 50 \%$ or control rabbits.

\section{Plasma biochemical components:}

Data of plasma biochemical components showed that the concentration of plasma albumin and glucose of rabbits fed diets containing 150 salix safsaf hay $\mathrm{Kg} / \mathrm{T}$ on or 225 salix safsaf hay $\mathrm{Kg} / \mathrm{Ton}$ ) were significantly lower ( $\mathrm{p} \leq$ 0.0311 and 0.05 ) than those group fed on T1 and T2 diets (Table 7). However, there were no significant differences among the experimental groups regarding the total protein and globulin. Increased total plasma protein and albumin of rabbits fed on diets containing 150 salix safsaf hay $\mathrm{Kg} /$ Ton or 225 salix safsaf hay $\mathrm{Kg} / \mathrm{Ton}$ ) diets was an indication of the relatively good protein quality and due to the level and availability of the dietary protein. However, total protein and albumin were within the ranges for healthy rabbits (Ajayi and Raji, 2012). Higher values obtained for the rabbits received T3 and T4 diet indicates that the tannin level of Salix saf saf hay was safe and beneficial that levels. Glucose concentrations of rabbits fed on T3 and T4 diet were lower $(\mathrm{P}<0.05)$ than those fed on $\mathrm{T} 2$ or $\mathrm{T} 1$ diets. The increase in plasma creatinine and plasma urea level and corresponding decrease in plasma glucose levels suggest that these constituents are negatively correlated. This is in support of Esonu et al. (2001) that animal will normally fall back to the stored energy in the muscles (phosphor creatine) when there is a reduction in blood glucose level. Depressed plasma glucose levels of rabbits fed on T3 and T4 diet possibly reflect the lower energy of Salix safsaf hay. Glucose levels were within the range indicated for healthy rabbits (Özkan et al., 2012), and it appears plausible to infer that the depressed serum glucose was due to tannic acid intoxication and/ or the animals were not surviving at the expense of body tissues.

In the terms of kidney function, urea nitrogen, $(\mathrm{mg} / \mathrm{dl})$ and uric acid, $(\mathrm{mg} / \mathrm{dl})$ had no significant affected $(\mathrm{p}=0.1711$ and 0.1612$)$ by replacement Salix safsaf with Berseem hay, while creatinine, $(\mathrm{mg} / \mathrm{dl})$ was significantly 
Table (6): Carcass characteristics of NZW rabbits as affected by dietary treatments

\begin{tabular}{|l|l|l|l|l|l|l|}
\hline \multirow{2}{*}{ Item } & \multicolumn{3}{|c|}{ Experimental diets } & \multirow{2}{*}{ SEM } & $\begin{array}{l}\text { P- } \\
\text { value }\end{array}$ \\
\cline { 2 - 6 } & T1 & T2 & T3 & T4 & & 0.5380 \\
\hline Pre-slaughter weight $(\mathrm{g})$ & 1777.2 & 1775.0 & 1796.0 & 1749.0 & 21.35 & 0.535 \\
\hline${\text { Carcass weight }(\mathrm{g})^{1}}^{1}$ & $1052.5^{\mathrm{b}}$ & $1102.5^{\mathrm{a}}$ & $1059.5^{\mathrm{ab}}$ & $1070.7^{\mathrm{ab}}$ & 14.90 & 0.0352 \\
\hline Dressing \% & 59.2 & 62.2 & 59.0 & 61.2 & 1.12 & 0.1755 \\
\hline${\text { Edible Giblets } \%^{2}}^{2}$ & 3.82 & 4.12 & 4.10 & 4.20 & 0.09 & 0.0686 \\
\hline${\text { Total edible parts } \%^{3}}^{\text {Total Non edible parts \% }}$ & $63.04^{\mathrm{b}}$ & $66.32^{\mathrm{a}}$ & $63.16^{\mathrm{b}}$ & $65.42^{\mathrm{ab}}$ & 1.05 & 0.0111 \\
\hline
\end{tabular}

$a$ and $\mathrm{b}$ : Means in the same row having different superscripts differ significantly $(\mathrm{P}<0.05)$

$\mathrm{SEM}=$ standard error of the mean.

1 Weight of hot carcass including head as percentage of pre-slaughter weight; ${ }^{2}$ Edible giblets $(\%)=($ liver $(\mathrm{g})+$ kidney $(\mathrm{g})+$ heart $(\mathrm{g})) /$ pre-slaughter weight $(\mathrm{g}) \times 100 \%$; ${ }^{3}$ Total edible parts as dressing $(\%)=($ carcass weight $(\mathrm{g})+$ weight of edible giblets $(\mathrm{g})) /$ Preslaughter weight $(\mathrm{g}) \times 100 \%$.

Table (7): Blood plasma biochemical metabolites of rabbits fed the dietary treatments.

\begin{tabular}{|c|c|c|c|c|c|c|}
\hline \multirow{2}{*}{ Item } & \multicolumn{4}{|c|}{ Experimental diets } & \multirow{2}{*}{ SEM } & \multirow{2}{*}{$\begin{array}{l}P \text { - } \\
\text { value }\end{array}$} \\
\hline & T1 & T2 & T3 & T4 & & \\
\hline Total Protein, (g/dl) & 5.62 & 5.79 & 6.09 & 6.01 & 0.30 & 0.5008 \\
\hline Albumin, (g/dl) & $3.59^{\mathrm{b}}$ & $3.50^{\mathrm{b}}$ & $3.97^{\mathrm{a}}$ & $4.13^{\mathrm{a}}$ & 0.46 & 0.0311 \\
\hline Globulin, (g/dl) & 2.03 & 2.29 & 2.12 & 1.88 & 0.92 & 0.1055 \\
\hline Glucose,$(\mathrm{mg} / \mathrm{dl})$ & $91.77^{\mathrm{a}}$ & $90.09^{\mathrm{a}}$ & $87.66^{b}$ & $89.94^{\mathrm{ab}}$ & 1.83 & 0.0500 \\
\hline Urea nitrogen,(mg/dl) & 62.22 & 61.94 & 60.03 & 59.91 & 3.39 & 0.1711 \\
\hline Uric acid, $(\mathrm{mg} / \mathrm{dl})$ & 0.49 & 0.50 & 0.51 & 0.52 & 0.19 & 0.1612 \\
\hline Creatinine, $(\mathrm{mg} / \mathrm{dl})$ & $0.60^{\mathrm{b}}$ & $0.63^{\mathrm{ab}}$ & $0.65^{\mathrm{a}}$ & $0.67^{\mathrm{a}}$ & 0.02 & 0.0051 \\
\hline Total lipids, (mg/l) & $401.25^{\mathrm{a}}$ & $387.75^{\mathrm{ab}}$ & $370.75^{b}$ & $332.50^{b}$ & 22.4 & 0.0171 \\
\hline Triglycerides, $(\mathrm{mg} / \mathrm{dl})$ & $56.06^{\mathrm{a}}$ & $40.09^{\mathrm{b}}$ & $40.28^{\mathrm{b}}$ & $32.31^{\mathrm{c}}$ & 2.40 & 0.0190 \\
\hline $\begin{array}{l}\text { Total } \\
(\mathrm{mg} / \mathrm{dl})\end{array}$ & $86.11^{\mathrm{a}}$ & $79.12^{\mathrm{b}}$ & $80.10^{\mathrm{ab}}$ & $70.30^{\mathrm{b}}$ & 6.03 & 0.0001 \\
\hline $\mathrm{HDL},(\mathrm{mg} / \mathrm{dl})$ & $48.87^{b}$ & $49.41^{b}$ & $54.68^{\mathrm{a}}$ & $54.66^{\mathrm{a}}$ & 0.98 & 0.0055 \\
\hline LDL, $(\mathrm{mg} / \mathrm{dl})$ & $36.21^{\mathrm{a}}$ & $30.92^{b}$ & $28.14^{\mathrm{b}}$ & $27.28^{\mathrm{b}}$ & 0.88 & 0.0015 \\
\hline $\mathrm{vLDL},(\mathrm{mg} / \mathrm{dl})$ & $13.25^{\mathrm{a}}$ & $10.98^{b}$ & $10.76^{\mathrm{b}}$ & $9.82^{\mathrm{b}}$ & 0.54 & 0.0036 \\
\hline AST,(IU) & $55.79^{\mathrm{a}}$ & $50.15^{b}$ & $49.65^{b}$ & $48.77^{b}$ & 0.47 & 0.0500 \\
\hline ALT, (IU) & $33.67^{\mathrm{a}}$ & $29.78^{b}$ & $30.11^{\mathrm{b}}$ & $29.47^{b}$ & 0.29 & 0.0500 \\
\hline $\begin{array}{l}\text { Alkaline phosphatase, } \\
(\mu \mathrm{l})\end{array}$ & $17.39^{\mathrm{a}}$ & $15.04^{\mathrm{ab}}$ & $13.42^{\mathrm{b}}$ & $12.15^{\mathrm{b}}$ & 0.21 & 0.0500 \\
\hline $\mathrm{TAC},(\mathrm{mmol} / \mathrm{l})$ & $0.789^{c}$ & $1.308^{\mathrm{b}}$ & $1.456^{\mathrm{ab}}$ & $1.647^{\mathrm{a}}$ & 0.054 & 0.0001 \\
\hline $\begin{array}{l}\text { Lipid } \\
\text { peroxides, }(\mathrm{mmol} / \mathrm{ml})\end{array}$ & $1.675^{\mathrm{a}}$ & $1.541^{\mathrm{ab}}$ & $1.394^{\mathrm{b}}$ & $1.212^{\mathrm{b}}$ & 0.71 & 0.0421 \\
\hline
\end{tabular}

$a$, b, and c: Means in the same row having different superscripts differ significantly $(\mathrm{P}<0.05)$

$\mathrm{SEM}=$ Standard error of the mean. 
increased with the salix safsaf levels in Berseem hay diets were increase ( $\mathrm{p}=$ $0.0050)$. The serum urea and creatinine levels were below the normal range of 8.1 - $25.0 \mathrm{mg} / \mathrm{l}$ and 1.4 - $16.6 \mathrm{mg} / \mathrm{l}$ reported by Kronfield and Mediway (1975) for rabbits reared in the temperate climate. The elevated creatinine concentration of rabbits displayed the decreased biological value of rabbits fed on T3 and T4 diets compared to those fed on T2 and control diets.

Plasma total lipids, cholesterol, triglycerides, LDL, (mg/dl) and vLDL, $(\mathrm{mg} / \mathrm{dl})$ levels were significantly decreased $(\mathrm{P} \leq 0.0171,0.0036,0.0001,0.0015$ and 0.0190) with increasing dietary levels of Salix safsaf, respectively. However, the concentration of HDL increased significantly $(\mathrm{p} \leq 0.0055)$ with increasing dietary Salix safsaf levels. This could be that salix safsaf inhibits the incorporation of 14C-labelled acetate into the non-saponifiable lipid fraction and thus reduced lipid profile biosynthesis and/ or it could have indirect inhibitory effects exerted at the levels of HMG-CoA reductase, a key enzyme in lipid biosynthesis. This would suggest that salix safsaf in rabbit diets were capable of reducing plasma lipid profile, thereby helping to reduce the deposition of cholesterol in the skin and muscles. This equally implies that salix safsaf could be incorporated in diets that will result in animal products with reduced cholesterol content. The fall in plasma cholesterol level of rabbits fed Salix Safsaf hay diets probably suggests a general decrease in lipid mobilization. The reduction in the total lipids, (mg/l), triglycerides, $(\mathrm{mg} / \mathrm{dl})$, total cholesterol, (mg/dl), LDL, (mg/dl) and vLDL, (mg/dl) level of rabbits fed Salix safsaf in barseem hay diets is in agreement with the findings of Salma et al. (2014) that Salix tetrasperma hay in the diets of rabbits resulted to a decrease in the total lipids, cholesterol and triglecerides levels. In term of the liver function, AST, (IU) and ALT, (IU) were affected with replacement different levels of salix safsaf to barseem hay diets. It was observed that AST, (IU) and ALT, (IU) levels were significantly decreased (P $\leq 0.0511$ and 0.0524) with increasing dietary levels of salix safsaf.

Plasma levels of AST and ALT activity are those conventionally used for diagnosing domestic animal hepatic damage, specifically, and are used to detect bile obstruction (i.e. mild and progressive damage to the liver). Normal ranges for AST and ALT are 42.5-98.0 and 48.5-78.9 IU/L (Ajayi and Raji, 2012). That none of these blood metabolites differed among diets, and that all of them fell within the normal ranges for rabbits, suggest that no damage had occurred in the liver. Rabbits, particularly those consumed salix safsaf which contained CT, did not show clinical signs of morbidity or signs of tannin toxicity. Absence of signs of ill health and mortality in rabbits that 
consumed T3 and T4 diets, in which CT were more concentrated, confirms the non-toxic level of CT in Salix safsaf. The same trend was observed for blood plasma alkaline phosphatase activity level (IU/L) which was significantly $(\mathrm{P}<0.0532)$ decreased with Salix Safsaf hay diets. The plasma alkaline phosphatase (ALP) values were within the standard range of 17-192 $\mu 1$ recommended for clinically healthy rabbits (Hewitt et al., 1989).

\section{Biomarkers of antioxidant status}

The effects of different levels of Salix Safsaf hay on blood antioxidant constituents of rabbits are presented in Table 7. A significant, dosedependent decrease $(\mathrm{p} \leq 0.001)$ of plasma Lipid peroxides, $(\mathrm{mmol} / \mathrm{ml})$ was observed in rabbits fed diets supplemented with salix safsaf with barseem hay. An opposite effect was noticed regarding TAC, $(\mathrm{mmol} / \mathrm{l})$, where the values were significantly $(\mathrm{p} \leq 0.0001)$ increased with increasing Salix Safsaf levels in the diets. As Lipid peroxides is present in lipoproteins, this blood constituent decreased with increasing dietary Salix Safsaf level like other lipids, cholesterol and triglycerides. In this respect, Sulaiman et al. (2013) recorded that Salix alba extract have good free radical scavenging activity and can be used as a radical inhibitor or scavenger, acting possibly as a primary antioxidant. Also, polyphenolic compounds are known to have antioxidant activity (Zheng and Wang, 2001; Chen et al., 2002; LuximonRamma et al., 2005 and Djeridane et al., 2006). This result is parallel with findings of Khayyal et al. (2005) and Sharma et al. (2011) who showed that willow bark extract reduced oxidative stress and increased glutathione (GSH) in several animal arthritis models. In the present study, an opposite effect was noticed regarding TAC, where the values were significantly increased with increasing Salix Safsaf levels. These results confirm that the antioxidant activity of phenolic compounds in willow (Salix) is mainly due to their reduction-oxidation (redox) reactions and chemical structure (Arsenov et al., 2017).

\section{Economic evaluation:}

Final body weight, length of the growing period and feeding cost are generally among the most important factors involved in achievement of maximum efficiency values of meat production. The relative economic efficiency (REE) of the different formulated diets as affected by different treatments is shown in Table 8. It should be pointed that the relative economic efficiency values were calculated according to the prevailing market selling price of $1 \mathrm{~kg} \mathrm{LBW}$. Results indicated that using salix safsaf 
Table (8): Economical efficiency as affected by dietary treatments.

\begin{tabular}{|l|c|c|c|c|}
\hline \multirow{2}{*}{ Items } & \multicolumn{4}{|c|}{ Treatment groups } \\
\cline { 2 - 5 } & T1 & T2 & T3 & T4 \\
\hline Total average weight gain (g) & 1997 & 1983 & 2052 & 2119 \\
\hline Price of 1kg body weight & 30 & 30 & 30 & 30 \\
\hline Selling price/rabbit (LE) (A) & 59.9 & 59.5 & 61.6 & 63.6 \\
\hline Total feed intake (Kg) & 5.448 & 5.395 & 5.391 & 5.312 \\
\hline Price/kg feed(LE) & 4.9 & 4.7 & 4.5 & 4.3 \\
\hline Total feed cost/rabbit (LE) (B) $^{\text {Net revenue(LE) }}{ }^{1}$ & 26.7 & 25.4 & 24.3 & 22.8 \\
\hline Economic efficiency $^{2}$ & 33.2 & 34.1 & 37.3 & 40.8 \\
\hline Relative Econ. Eff. $^{3}$ & 1.24 & 1.34 & 1.54 & 1.79 \\
\hline
\end{tabular}

(1) Net revenue $=\mathrm{A}-\mathrm{B}$.

(2) Economic efficiency $=(\mathrm{A}-\mathrm{B} / \mathrm{B})$.

(3) Relative Economic Efficiency= Economic efficiency of treatments other than the control/ Economic efficiency of the control group.

as replacement of Berseem hay in growing rabbit diets improved slightly the net revenue and reduced the total feed cost. The lowest total feed cost / rabbit $(22.8 \mathrm{LE})$ was observed with rabbits fed the diets $(225$ salix safsaf +75 Berseem hay $\mathrm{Kg} / \mathrm{Ton})$. Data showed that $75 \%$ Salix Safsaf hay in Berseem hay diet to growing rabbit gave the best economic efficiency (1.79). The results indicated that 75, 150 and $225 \mathrm{Kg} /$ Ton Salix Safsaf hay as a partial replacement for $300 \mathrm{Kg} /$ Ton Berseem hay improved the REE of diets by 107.97, 123.45 and $143.91 \%$, respectively when compared with the rabbits fed on $300 \mathrm{Kg} / \mathrm{Ton}$ Berseem hay diet. While the economic efficiency values were raised with salix safsaf in Berseem hay diets 8.07, 24.19 and 44.36\%, respectively, compared with rabbits fed the control diets. No available feasibility study about the cost of diets when Safsaf hay is partial replaced Berseem hay.

Conclusion, Salix Safsaf hay can be considered as good source of principle compounds as Berseem hay. The results of the study revealed that all tested levels of Salix Safsaf hay were useful as a natural feed substitution with Berseem hay to maintain performance, carcass traits and antioxidant status and could reduce the negative effects of feed cost for rabbits.

\section{REFERENCE}

Ajayi, A.F., Raji, Y., (2012): Hematological and serum biochemical indices of pre-pubertal male rabbits fed with graded level of bloodwild sunflower forage meal mixture. African Journal of Biotechnology, 11(35): 8730-8734. 
Al-Fataftah, A.R. and Abdelqader, A. (2013): Effect of Salix babylonica, Populus nigra and Eucalyptus camaldulensis extracts in drinking water on performance and heat tolerance of broiler chickens during heat stress. American-Eurasian Journal of Agriculture and Environmental Science, 13 (10): 1309-1313.

AOAC (1996): Association of Official Analytical Chemists Association of Official Analytical Chemists $16^{\text {th }}$ Edn., Gaithersburd, MD, USA.

Arsenov, D.; Zupunski, M.; Borisev, M.; Nikolic, N.; Orlovic, S.; Pilipovic, A. and Pajevic, S. (2017): Exogenously Applied Citric Acid Enhances Antioxidant Defense and Phytoextraction of Cadmium by Willows (Salix Spp.). Water Air Soil Pollut, 228: 221.

Barry, T.N. and McNabb, W.C., (1999): The implications of condensed tannins on the nutritive value of temperate forages fed to ruminants. $\mathrm{Br}$. J. Nutr. , 81, 263-272.

Blasco, A., J. Quhayaun and G. Masoscro, (1993): Harmonization of criteria and terminology in rabbit meat research. World Rabbits Sciences, 1: 3-10.

Bissett NG. (1994): Herbal drugs and phytopharmace uticals. Stuttgart: MedPharm CRC Press, 566.

Blaxter, K.L., (1968): The Energy Metabolism of Ruminants. 2 Ed. Charles Thomas Publisher, Spring Field. Illinois, U.S.A.

Calsamiglia, S., Stem, M.D. and Frinkins, J.L. (1995): Effects of protein source on nitrogen metabolism in continuous culture and intestinal digestion in vitro. J. Anim. Sci., 73: 1819.

Caraway, A. (1963): In: Seligron, D. (Ed.), Standared Methods Of Clinical Chemistry. Vol. 4. Academic Pree, New York, 239.

Cheeke, P. R. (1986): Potential of rabbit production in tropical and subtropical agricultural Systems. Journal Animal Science, 63:1581- 1586.

Cheeke, P.R., Patton, N.M. and Tempelton, G.S. (2013): Rabbit production. $9^{\text {th }}$ Edition, Interstate, Danville IL., USA.

Chen, H.G., Yu, Y.G. and Zeng, O.X. (2002): Study on extraction of flavonoids and Alkaloids from lotus leaf. Food Sci., 23: 69-71.

Chiu D.T.Y., Stults, F.H., Tappel, A.L. (1976): Purification and properties of rat lung soluble glutathione peroxidase. Biochim Biophys Acta. 445:558-566.

De Blas, J. C. and Garvey, J. P. (1975): A note on the retention of energy and nitrogen in rabbits. Animal Production, 21, 345-347. 
De Blas, J.C. and Mateos, G.G. (1998): Feed Formulation. In: De Blas, J. C. and Wiseman, J. (Eds.).The nutrition of the rabbit. CABI Pub I., Wallingford, UK. pp. $241-253$.

De Blas, J.C., García, J. and Carabaño, R. (1999): Role of fiber in rabbit diets. A review, Animal Zootechnology, 48: 3-13.

Djeridane, A., Yousfi, M., Nadjemi, B., Boutassouma, D. and Stocker, P. (2006): Antioxidant activity of some Algerian medicinal plants extracts containing phenolic compounds. Food Chem., 97: 654-660.

Duncan, D.B. (1955): Multiple Rang and Multiple F-Test. Biometrics, 11: 1-42.

Esonu, B.O., Emenalom, O.O., Udedibie, A.B.I., Herbert, U., Ekpor, C.F., Okoli, I.C. and Ihukwumere, F.C. (2001): Performance and blood chemistry of weaner pigs fed raw Mucuna beans (Velvet bean) meal. Trop. Anim. Prod. Invest., 4:49-54.

Fawcett, J.W. and Soctt, J.E. (1960): A rapid and precise method for the determination of urea. J. Clin. Path., 13:156- 159.

Fekete, S. and Gippert, T. (1986): Digestibility and nutritive value of nineteen important feedstuffs for rabbits. J. Appl. Rabbit Res., 9(3): 103-108.

Fotsch, G.; Pfeifer, S.; Bartoszek, M.; Franke, P. and Hiller, K. (1989): Biotransformation of phenolglycosides leiocarposide and salicin. Pharmazie; 44:555-8.

Garcia, J.; Gidenne, T.; Falcao e Cunha, L. and de Blas, C. (2002): Identification of the main factors that influence caecal fermentation traits in growing rabbits. Animal Research, 51, 165-173.

Goering, H.K. and Van Soest, P.J. (1970): Forge Fiber Analysis (Apparatus, Reagents, Procedure and Some Applications). Agric. Hand Book 379, USDA, Washington and DC., USA.

Guevara-Escobar, A., (1999): Aspects of a willow pasture system related to pasture production in New Zealand. Ph.D, Thesis, Massey University, New Zealand.

Hewitt, C.D., Innes, D.J. Savory, and Wills, M.R. (1989): Normal biochemical and hematological values of New Zealand white rabbits. Clin. Chem. 35/8.

Ibrahim Sh.A.M., El-Ghamry A.A., El-Mallah G.M. (2000): Effect of some medicinal plants of Labiatae family as feed additives on growth and metabolic changes of rabbits. Pages: 105-120 Volume 10, Number 1. 
Jo Smith; Kaisa Kuoppala; David Yáñez-Ruiz; Katharine Leach and Marketta Rinne. (2014): Nutritional and fermentation quality of ensiled willow from an integrated feed and bioenergy agroforestry system in UK. Maataloustieteen Päivät, 2014.

Julkunen-Tiitto R. and Meier B. (1992): The enzymatic decomposition of salicin and its derivatives obtained from Salicaceae species. Journal of Natural Products; 55:1204-12.

Khayyal, M.T., El-Ghazaly, M.A., Abdallah, D.M., Okpanyi, S.N., Kelber, O. and Weiser D. (2005): Mechanisms involved in the antiinflammatory effect of a standardized willow bark extract. Arzneimitt elforschung, 55: 677-687.

Kronfield, O.W. and Mediway, N.C. (1975): Blood Chemistry. In; Textbook Of Veterinary and Clinical Pathology Publ. Williams and Williams Co. Baltimore, pp.18-96.

Lise Manniche, (1989): An Ancient Egyptian Herbal, University of Texas Press.

Luximon-Ramma, A., T. Bahorun, A.M. Soobrattee and O.I. Aruoma, (2005): Antioxidant activities of phenolic, proanthocyanidin and flavonoid components in extracts of cassia fistula. J. Agric. Food Chem., 50: 5042-5047.

Maertens L., Cornez B., Vereecken M. and Van Oye S., (2005): Efficacy study of soluble bacitracin (Bacivet S) in a chronically infected epizootic rabbit enteropathy environment. World Rabbit Sci., 13, 165-178.

Makkar, H.P.S. (2003): Quantification of Tannins in Tree and Shrub Foliage. Kluwer Academic, Dordrecht, pp. 102.

McDougall, G.J., Shpiro, F.; Dobson, P.; Smith, P.; Blake, A. and Stewart, D. (2005): Different polyphenolic components of soft fruits inhibit alphaamylase and alpha-glucosidase. J. Agric. Food Chem., 6(53) (7): 27602766.

McWilliam, E.L.H. (2004): The Effect of Poplar (Populus spp.) and Willow (Salix spp.); Supplementation on the reproductive performance of ewes grazing low quality drought pasture during mating. Animal Feed Science and Technology, 115, 1-18.

Meier, B., Julkunen-Tiitto, R., Tahvanainen, J. and Sticher, O., (1988): Comparative high-performance liquid and gas-liquid chromatographic determination of phenolic glucosides in Salicaceae species. Journal of Chromatography, 442, 175-186.

N.R.C. (1977): National Research Council. Nutrient Requirements of Rabbits. National Academy of Science, Washington, D.C, USA. 
Nicodemus, N., Carabano, R., Garcia, J., Mendez, J. and De Blas, C. (1999): Performance response of lactating and growing rabbits to dietary lignin content. Animal Feed Science and Technology, 80, 43-54.

Özkan, C., Kaya, A. and Akgül, Y. (2012): Normal values of hematological and some biochemical parameters in serum and urine of New Zealand White rabbits. World Rabbit Science, 20, 253 - 259.

Partridge, G., Ganhawaite, P.H. and Findlay, M. (1989): Protein and energy retention by growing rabbits offered with increasing proportions of fiber. Journal of Agricultural Science, 112: 171- 178.

Pitta, D.W., Barry, T.N., López-Villalobos, N. and Kemp, P.D. (2007): Willow fodder blocks - an alternate forage to low quality pasture for mating ewes during drought? Animal Feed Science and Technology, 133, 240-258.

Provenza, F.D. (1995): Post ingestive feedback as an elementary determinant of food selection and intake in ruminants. J. Range Manage. 48, 2-17.

Rizzi, C. and Chiericato, G.M. (2008): Effect of environmental conditions on productive and physiological responses in growing rabbits. $9^{\text {th }}$ World Rabbit Congress, June 10-13, Verona, Italy.

Salma H. AbuHafsa; Hassan, A.A.; Camacho, L.M.; Abdelfattah Z. and Salem, M. (2014): Replacement of berseemhay by Salix tetrasperma on physiological performance of New Zealand White rabbits under subtropical conditions of Egypt. Trop. Anim. Health Prod., 46:11191125.

Salem A.Z., Robinson P.H., El-Adawya M.M., and Hassan A.A. (2007): In vitro fermentation and microbial protein synthesis of some browse tree leaves with or without addition of polyethylene glycol. Anim. Feed Sci. Technol. 138, 318-330.

Salem A.Z.M., Salem M.Z.M.., El-Adawy M.M., and Robinson P.H. (2006): Nutritive evaluations of some browse tree foliages during the dry season: Secondary compounds, feed intake and in vivo digestibility in sheep and goats. Anim. Feed Sci. Technol. 127, 251-267.

Salem, A.Z.M. (2005): Impact of season of harvest on in vitro gas production and dry matter degradability of Acacia saligna leaves with inoculum from three ruminant species. Anim. Feed Sci. Technol. 123-124, 67-79.

Saller, R., J. Melzer and M. Felder, (2008): Pain relief with a proprietary extract of Willow bark in rheumatology. An Open Trial. Schweiz. Zschr. Ganzheits Medizin, 20: 156-162. 
SAS, (2001): SAS/STAT Software, Release 8.02. SAS Institute Inc. Cary, North Carolina.

Sharma, S., Sahu, D., Das, H.R. and Sharma, D. (2011): Amelioration of collagen-induced arthritis by Salix nigra bark extract via suppression of pro-inflammatory cytokines and oxidative stress. Food Chem. Toxicol.

Silva,D.J. and Queiroz, A.A.C. (2002): Analysis Foods: Chemical And Biologicalmethods.3. ed. Viçosa, MG: UFV, 235p.

Steven Lukefapor, W.D; Hohenboken, W.D.; Cheeke, P.R.; Patton, N.M. and Kennick, W.H. (1981): Carcass and meat characteristics of Flemish giant and New Zealand white purebred and terminal cross rabbits. Journal of Applied Rabbit Research, 4 (3): 66-72.

Sulaiman, G.M.; Hussien, N.N.; Marzoog, T.R. and Awad, H.A. (2013): Phenolic content, antioxidant, antimicrobial and cytotoxic activities of ethanolic extract of salix alba. American Journal of Biochemistry and Biotechnology, 9 (1): 41-46.

Szasz, G. (1969): A Kinetic Photometric Method for Serum -Glutamyl Transpeptidase. Clinical Chemistry, 15: 124-136.

ThiMui, N., Dinh Van, B. and Ørskov, E.R. (2005): Effect of foliages containing condensed tannins and on gastrointestinal parasites. Animal Feed Science Technology, 121, 77-87.

Trinder P. (1969): Determination of glucose in blood using gluco-seoxidase with an alternative oxygen acceptor. Ann Clin Biochem., 6:24-27.

Zheng, W. and S.Y. Wang, (2001): Antioxidant activity and phenolic compounds in selected herbs. J. Agric. Food Chem., 49: 5165-5170. 
EVALUATION OF EGYPTIAN TREE WILLOW LEAVES AND ON RABBITS 61

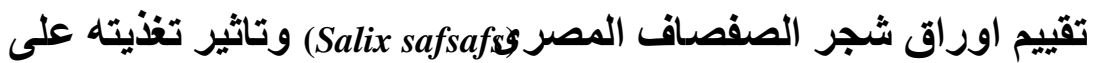
الأداء الأنتاجى للار انب النيوزيلاندى البيضباء

محمد بسيونى محمد محمود1، ايمان اسماعيل عبد الجوأل رجب محمد عبد المنعج

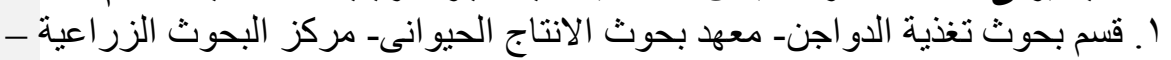

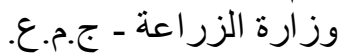

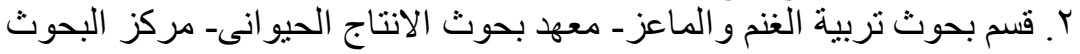

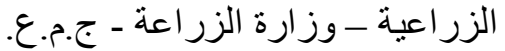
r. معهد بحوث التناسليات، مركز البحوثة اعه الزر اعيه، الدقي، الجيزه، مصر.

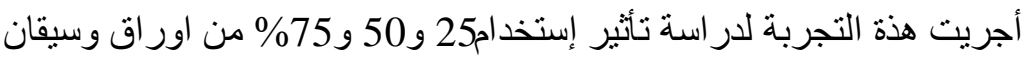
شجر الصفصاف إحلال من دريس البرسيمعلى الأداء الأنتاجى للأر انب الناميةتم تقسيم النيان

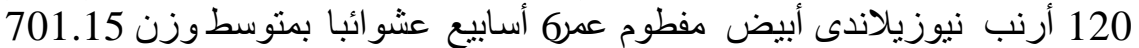

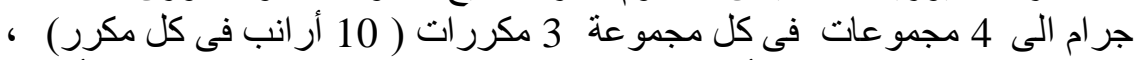

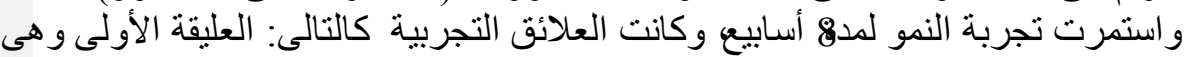

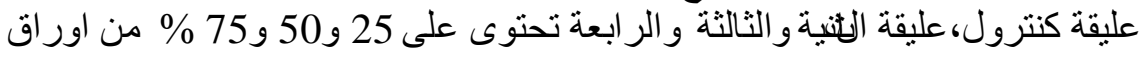

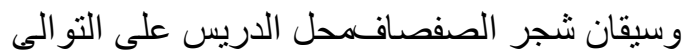
يكن تلخيص النتائج كما بلى:

1 - وجود تحسن معنوى فيىوزن الجسم النهائى الزيادة الوزنية اليوميةت كفاءة التحويل

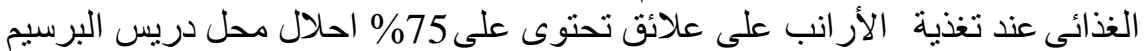

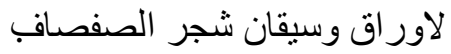

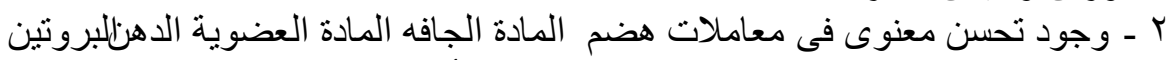

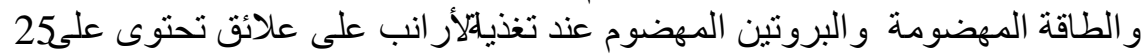
و50 و75\% من اور اق وسيقان شجر الصفصاف. بينما لم بلاحظ أى تأثئير معنوى بين المعاملات المختلفة في معامل هضم التم الالياف

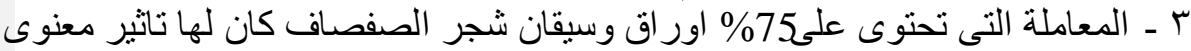

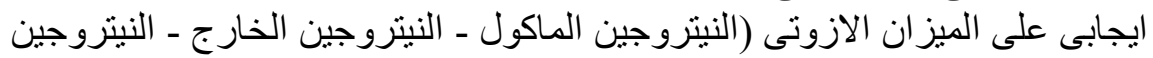

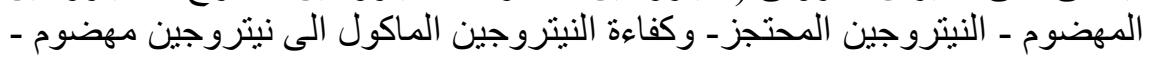

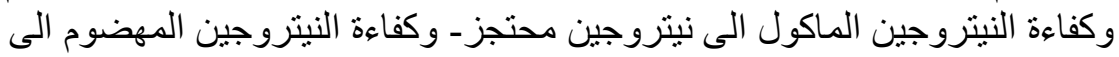

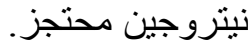




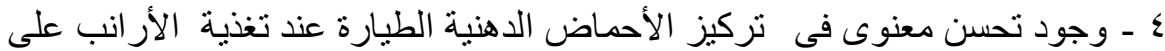

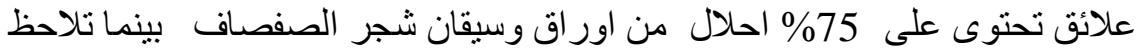
انخفاض معنوى في تركيز الامونيا

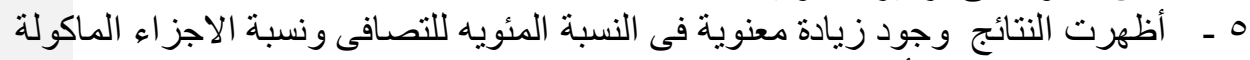

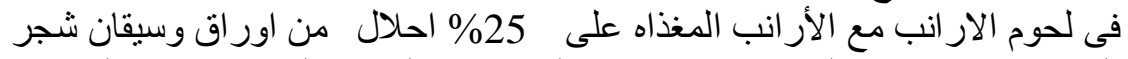

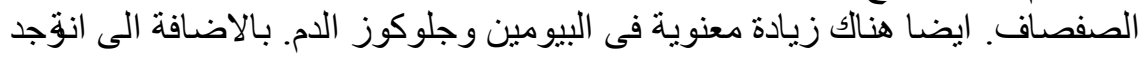

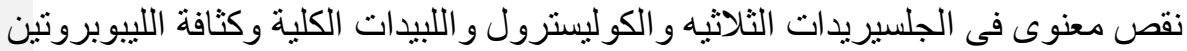

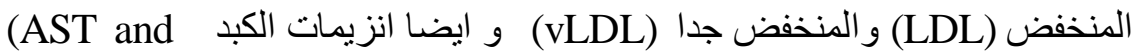

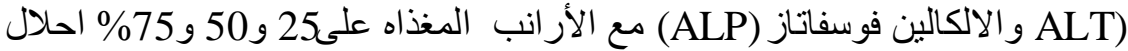

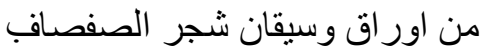

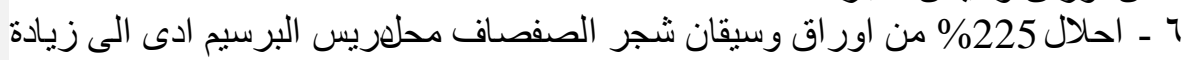

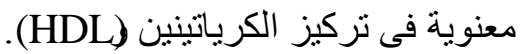

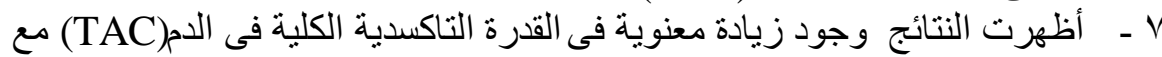

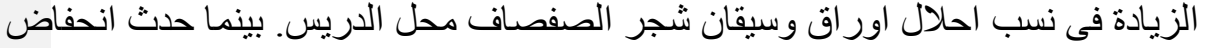

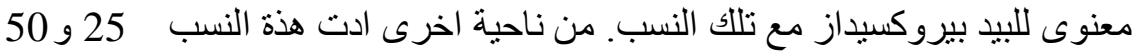

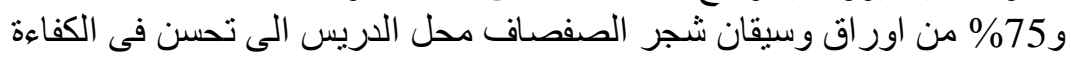
الاقتصادية لاعلاف الار انب.

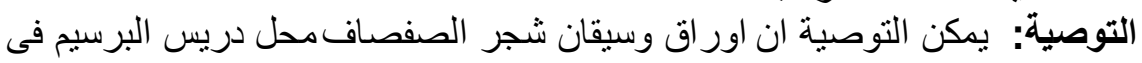
علائق الأر انب حتى مستوى 75\% يحسن من الأداء الأنتاجى و الكفاءة الأقتصادية الئرسية لأنتاج الأر انب الأب أب 